\title{
Does a reduction of vascular relaxation promote hypertension?
}

\author{
Kathrin Schulte ${ }^{*}$ Doris Koesling, Evanthia Mergia \\ From 5th International Conference on cGMP: Generators, Effectors and Therapeutic Implications \\ Halle, Germany. 24-26 June 2011
}

\section{Background}

Alterations in vascular relaxation have been reported in various models of hypertension. With its tonic activity, the NO/cGMP signalling cascade plays an important role in the regulation of the vascular tone. In blood vessels, NO is continuously being produced by the endothelial NO synthases (eNOS) which leads to cGMP production by stimulating the NO-sensitive guanylyl cyclases (NO-GCs). In vascular smooth muscle cells, two NO-GC isoforms, NO-GC1 and NO-GC2, mediate relaxation, with $\mathrm{NO}-\mathrm{GC} 1$ being responsible for approximately $90 \%$ of the NO-stimulated cGMP formation. Deletion of eNOS or both NO-GCs abrogates endothelium-dependent relaxation and causes substantial hypertension. However, deletion of only NO-GC1 does not lead to hypertension despite a $50 \%$ reduction of endothelium-dependent relaxation.

\section{Results}

To investigate whether reduced vascular relaxation promotes the development of hypertension, we induced hypertension in NO-GC1 $\mathrm{KO}$ and wild-type (WT) mice by treating the mice with angiotensin II treatment (1.44 $\mathrm{mg} / \mathrm{kg} \mathrm{BW} / \mathrm{d}$ ) for two weeks. As expected, angiotensin II treatment induced profound hypertension. However, blood pressure increases $(\sim 40 \mathrm{mmHg})$ and reduction in endothelium-dependent relaxation were similar in $\mathrm{KO}$ and WT mice. Also angiotensin IIinduced increases in total peripheral resistance as measured in hind-limb perfusion experiments were indistinguishable. Interestingly, NO-GC1 KO mice displayed $35 \%$ higher basal peripheral resistance in these experiments.

\footnotetext{
* Correspondence: kathrin.schulte@ruhr-uni-bochum.de Department of Pharmacology and Toxicology, Ruhr-Universität-Bochum, Germany
}

\section{Conclusion}

Taken together, reduction of NO-stimulated cGMP production in blood vessels by $90 \%$ does not exaggerate angiotensin II-induced hypertension. The mechanisms underlying this finding have to be investigated.

Published: 1 August 2011

doi:10.1186/1471-2210-11-S1-P64

Cite this article as: Schulte et al:: Does a reduction of vascular relaxation promote hypertension? BMC Pharmacology 2011 11(Suppl 1):P64.
Submit your next manuscript to BioMed Central and take full advantage of:

- Convenient online submission

- Thorough peer review

- No space constraints or color figure charges

- Immediate publication on acceptance

- Inclusion in PubMed, CAS, Scopus and Google Scholar

- Research which is freely available for redistribution 